\title{
SISTEM INFORMASI GEOGRAFIS UNTUK PENCARIAN LOKASI BENGKEL MOBIL DI WILAYAH KOTA BANDAR LAMPUNG
}

\author{
A. Ferico Octaviansyah Pasaribu ${ }^{1)}$, Dedi Darwis ${ }^{2)}$, Agus Irawan ${ }^{3)}$, Ade Surahman ${ }^{4)}$ \\ 1), 2),4) Fakultas Teknik dan Ilmu Komputer, Universitas Teknokrat Indonesia \\ ${ }^{3}$ Sistem Informasi, STMIK Pringsewu \\ Jl. H.ZA Pagaralam, No 9-11, Labuhanratu,Bandarlampung \\ Email :fericopasaribu@teknokrat.ac.id ${ }^{1)}$, darwisdedi@teknokrat.ac.id. ${ }^{2)}$,agusirawan814@gmail.com ${ }^{3)}$, \\ adesurahman@teknokrat.ac.id ${ }^{3)}$
}

\begin{abstract}
Abstrak
Perkembangan dunia otomotif di wilayah kota Bandar Lampung berkembang dengan pesat, dengan banyaknya lokasi bengkel di wilayah ini terkadang masih membuat bingung para pengguna layanan bengkel dalam menemukan lokasi bengkel terdekat atau bengkel yang akan dicari karena pada umumnya bengkel hanya mencantumkan nama bengkel dan alamatnya saja terutama bagi bengkel resmi. Hal ini akan menyebabkan permasalahan bagi pengguna layanan bengkel yang tidak semuanya mengetahui nama bengkel dan alamat yang tercantum pada buku panduan, terutama bagi pengguna layanan bengkel yang berdomisili di luar kota Bandar Lampung. Tujuan dari penelitian ini adalah mengembangkan aplikasi sistem informasi geografis dengan memanfaatkan Google Maps API untuk pemetaan bengkel mobil di wilayah Kota Bandar Lampung untuk mencari lokasi bengkel terdekat atau bengkel yang akan dicari oleh pengguna layanan bengkel dengan harapan dapat mempermudah dan membantu dalam proses pencarian lokasi dan meningkatnya penggunaan jasa layanan bengkel di kota Bandar Lampung. Berdasarkan hasil dari dua proses pengujian yang dilakukan yaitu black box testing dan user acceptance testing membuktikan bahwa aplikasi ini secara fungsionalitas dapat berfungsi dengan baik dan menghasilkan nilai 84,04\% dengan skor aktual sangat baik untuk pengujian user acceptance testing.
\end{abstract}

Kata kunci: Bengkel Mobil, Google Maps API, Sistem Informasi Geografis

\section{Pendahuluan}

\section{A. Latar Belakang}

Perkembangan dunia otomotif dimasyarakat semakin pesat, hal ini terlihar dari banyaknya kendaraan motor dan mobil sehingga mendorong pihak produsen mobil untuk terus selalu membuat dan mengembangkan bengkel resmi maupun bengkel tidak resmi karena hal ini dimaksudkan untuk memudahkan para pengguna memperbaiki mobilnya ketika mengalami kerusakan.

Kota Bandar Lampung adalah sebuah kota di Indonesia sekaligus ibukota dan kota terbesar di Provinsi Lampung. Bandar Lampung juga merupakan kota terbesar dan terpadat ketiga di Pulau Sumatra setelah
Medan dan Palembang menurut jumlah penduduk, serta termasuk salah satu kota besar di Indonesia dan Kota terpadat di luar pulau Jawa (BPS, 2019). Dengan cukup padatnya masyarakat di kota Bandar Lampung maka volume kendaraan di kota ini juga cukup banyak terutama mobil karena dengan banyak kendaraan maka banyak produsen ataupun perseorangan tertarik berbisnis dibidang perbaikan otomotif dan bengkel. Berdasarkan hasil observasi yang telah dilakukan terdapat lebih dari 50 bengkel mobil resmi dan tidak resmi yang berada di wilayah kota Bandar Lampung dan dibeberapa wilayah perbatasan kota Bandar Lampung.

Banyaknya lokasi bengkel di wilayah kota Bandar Lampung terkadang masih membuat bingung para pengguna layanan bengkel dalam menemukan lokasi bengkel terdekat atau bengkel yang akan dicari karena pada umumnya bengkel hanya mencantumkan nama bengkel dan alamatnya saja terutama bagi bengkel resmi. Hal ini akan menyebabkan permasalahan bagi pengguna layanan bengkel yang tidak semuanya mengetahui nama bengkel dan alamat yang tercantum pada buku panduan, terutama bagi pengguna layanan bengkel yang berdomisili di luar kota Bandar Lampung.

Salah satu cara agar dapat mempermudah pengguna layanan bengkel untuk mencari lokasi bengkel adalah dengan menggunakan Sistem Informasi Geografis (SIG) yaitu sistem komputer yang digunakan untuk mengumpulkan, memeriksa, mengintegrasikan, dan menganalisa informasi-informasi yang berhubungan dengan permukaan bumi yang disajikan dalam benttuk peta (Wibowo dan Mukti, 2015). SIG akan memanfaatkan konsep visualisasi peta dengan Google Maps yaitu sebuah jasa peta global virtual gratis dan online yang disediakan oleh Google dan dapat ditemukan di http://maps.google.com. Google Maps memberikan layanan untuk menunjukkan jalan-jalan yang ada di seluruh dunia (Mnarni,2013). Google Maps Application Programming Interface (API) adalah fungsi fungsi pemrograman yang disediakan oleh Google Maps agar Google Maps bisa diintegrasikan ke dalam Web atau Smartphone. Dengan penggunaan Google Maps API proses pencarian lokasi melalui peta atau dalam mengklasifikasikan wilayah akan menjadi lebih mudah dan cepat (Darwis, 2016). Pengembangan aplikasi yang memanfaatkan Google Maps API pasti menggunakan Global Positioning 
System (GPS) yaitu satu-satunya sistem navigasi satelit. Sistem ini menggunakan 24 satelit yang mengirimkan sinyal gelombang mikro ke bumi. Sinyal ini diterima oleh alat penerima di permukaan, dan digunakan untuk menentukan posisi, kecepatan, arah dan waktu (Indrakarna dan Yudisuda, 2012).

Penggunaan SIG telah banyak dimanfaatkan, sebagai contoh telah digunakan untuk pemetaan bengkel sepeda motor di kota Kisaran berbasis website dengan hasil penelitian dapat mempermudah masyarakat pada kota Kisaran dalam mencari bengkel terdekat atau bengkel yang mereka cari dengan visualisasi peta dan mengarahkan ke lokasi yang dituju (Eska, 2018). Penelitian tentang SIG juga dterapkan pada pemetaan kolam renang umum di kota Medan berbasis platform android dengan hasil penelitian berupa aplikasi untuk pemetaan kolam renang umum di kota Medan berbasis android dengan harapan masyarakat dapat dengan mudah menemukan lokasi kolam renang di kota Medan beserta informasi tentang harga dan fasilitas yang ada pada kolam renang di kota Medan (Sanjaya, 2014).

Tujuan dari penelitian ini adalah mengembangkan aplikasi sistem informasi geografis dengan memanfaatkan Google Maps API untuk pemetaan bengkel mobil di wilayah kota Bandar Lampung untuk mencari lokasi bengkel terdekat atau bengkel yang akan dicari oleh pengguna layanan bengkel dengan harapan dapat mempermudah dan membantu dalam proses pencarian lokasi dan meningkatnya penggunaan jasa layanan bengkel di kota Bandar Lampung.

\section{B. Penelitian Terkait}

Penelitian yang dilakukan oleh Kumalawati, et.al (2013) dengan judul : Aplikasi Sistem Informasi Geografis dan Penginderaan untuk Estimasi Kerusakan Pemukiman akibat Banjir Lahar di Kecamatan Ngluwar Magelang. Penelitian ini membahas tentang aplikasi SIG dan penginderaan jauh untuk memetakan estimasi kerusakan pemukiman akibat banjir lahar di kecamatan Ngluwar dengan menggunakan citra Ikonis dan beberapa peta pendukungnya.

Penelitian yang dilakukan oleh Irwansyah, et.al (2013) dengan judul : Pengembangan Sistem Informasi Geografis pada Platform Google untuk Penanggulangan Kebakaran di Jakarta Selatan. Hasil dari penelitian ini antara lain adalah pemanfaatan aplikasi SIG khususnya menggunakan website yang berguna untuk pemadam kebakaran sebagai alat bantu untuk menanggulangi bahaya kebakaran khusunya di Jakarta Selatan. Pemanfaatan SIG ini juga memberikan informasi yang berguna bagi masyarakat mengenai persebaran titik rawan kebakaran dan titik penanggulangan terdekat sehingga masyarakat harus tetap waspada terhadap potensi kebakaran yang dapat terjadi setiap saat.

Penelitian yang dilakukan oleh Eska (2018) dengan judul : Geographic Information System Pemetaan Bengkel Sepeda Motor di kota Kisaran Berbasis Web. Penelitian ini membahas tentang permasalahan sulitnya pencarian lokasi bengkel di kota Kisaran yang menyebabkan pengguna layanan jasa bengkel sepeda motor untuk mengetahui bengkel terdekat dan sesuai kebutuhan dan tidak adanya petunjuk arah yang jelas mengenai lokasi bengkel yang dapat menyulitkan pengguna dalam menemukan bengkel yang dicari. Hasil dari penelitian ini adalah berupa aplikasi SIG berbasis web yang dapat mempermudah para pengguna jasa bengkel sepeda motor dalam menemukan bengkel yang dicari.

Berdasarkan beberapa penelitian terkait yang telah dipaparkan maka perbedaan antara penelitian sebelumnya dengan penelitian yang dibuat adalah :

1) Objek lokasi pencarian adalah pada bengkel mobil resmi dan tidak resmi di wilayah Kota Bandar Lampung.

2) Aplikasi yang dibangun menggunakan platform android.

3) Google Maps API yang digunakan sudah menggunakan versi berbayar yang artinya memiliki lebih banyak fitur dan perbaikan-perbaikan algoritma pada Google Maps API sehingga hasil pencarian pada peta akan lebih optimum.

\section{Pembahasan}

\subsection{Rancangan Penelitian}

Rancangan penelitian tentang pencarian lokasi bengkel mobil menggunakan sistem informasi geografis pada Gambar 1.

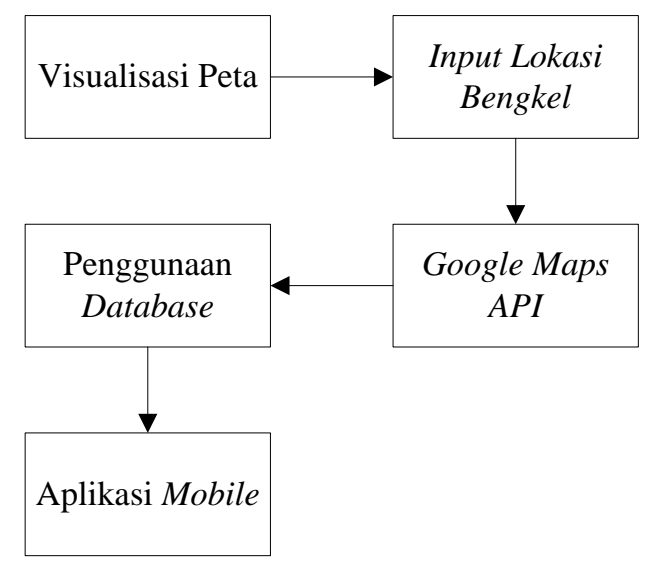

Gambar 1. Rancangan Penelitian

Penjelasan pada Gambar 1 :

1) Visualisasi peta lokasi bengkel mobil resmi menggunakan Google Maps yang sudah tersedia di smartphone Android.

2) Input Lokasi bengkel sesuai dengan interface yang telah dibuat untuk mempermudah pengguna dalam melakukan pencarian bengkel sesuai dengan yang dicari atau melakukan pencarian bengkel terdekat.

3) Google Maps API akan tampil setelah pengguna memasukkan bengkel yang akan dicari setelah itu peta yang dimanfaatkan melalui Google Maps akan ditampilkan dengan menunjukkan titik awal lokasi pencarian ke titik lokasi yang dituju. 
4) Penggunaan Database sangat diperlukan untuk memasukkan semua data lokasi bengkel resmi dan tidak resmi di lokasi kota Bandar Lampung.

5) Pemanfaatan pencarian lokasi bengkel mobil ini hanya digunakan untuk pengguna yang ingin mencari lokasi bengkel mobil di wilayah Bandar Lampung dan sekitarnya.

\subsection{Jenis Data}

Pada penelitian ini menggunakan berbagai macam data khususnya data kualitatif. Data kualitatif ini berupa data lokasi yang dicari oleh pengguna yang selanjutnya diolah menggunakan visualisasi peta. Dalam penelitian ini juga digunakan data kuantitatif yang berkaitan dengan visualisasi peta Google Maps. Visualisasi peta Google Maps dihasilkan melalui peta Google Maps menggunakan titik koordinat $(\mathrm{x}, \mathrm{y})$ untuk mencari lokasi bengkel mobil.

\subsection{Klasifikasi Data}

Berdasarkan diskusi yang dilakukan peneliti dengan pengguna yang memiliki kendaraan roda empat/mobil, peneliti dapat mengklasifikasikan jenis data/informasi, yaitu :

1) Data/Informasi Umum

Merupakan data/informasi yang bersifat global dan semua pihak dapat menggunakannya, yaitu data produsen mobil, data nama bengkel mobil resmi data lokasi bengkel mobil.

2) Data/Informasi Khusus

Merupakan data/informasi yang bersifat privasi dan tidak semua pihak dapat menggunakannya, yaitu data administrator. Data administrator digunakan untuk masuk ke dalam sistem sebelum mengisi data produsen mobil, data nama bengkel mobil dan data lokasi bengkel mobil. Sehingga hanya pengguna yang berstatus administrator yang dapat mengisi data-data tersebut.

\subsection{Tahapan Penelitian}

Tahapan-tahapan penelitian dapat dideskripsikan pada Gambar 2.

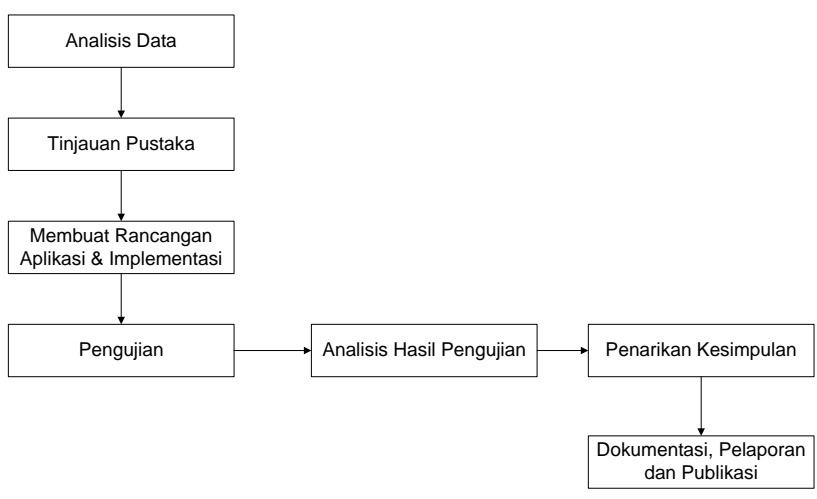

Gambar 2. Tahapan Penelitian
Penjelasan pada Gambar 2 :

1) Analisis Data

Langkah ini bertujuan untuk mengetahui namanama bengkel mobil beserta titik lokasi dan alamat di wilayah Kota Bandar Lampung dan sekitarnya. Data yang dikumpulkan berupa daftar nama bengkel dan lokasi beserta titik koordinat petanya pada Google Maps.

2) Melakukan Tinjauan Pustaka

Penelitian ini dimulai dengan melakukan studi pustaka yang berkaitan dengan konsep penerapan sistem informasi geografis, serta penggunaan Google Maps API. Tinjauan pustaka dilakukan dengan mengumpulkan semua literatur berupa jurnal, prosiding dan buku yang berkaitan dengan topik penelitian yang dibahas.

3) Membuat Rancangan Aplikasi \& Implementasi Langkah selanjutnya adalah membuat rancangan yang berkaitan dengan penerapan sistem informasi geografis. Adapun rancangan yang dibuat adalah berupa rancangan Use Case, Flowcharat, Rancangan Basis Data dan Interface Program yang menggambarkan bagaimana sistem akan dijalankan oleh para aktor atau user.

4) Pengujian

Pada tahap ini peneliti melakukan simulasi dan pengujian yaitu dengan menggunakan Black box dan User acceptance testing dengan melibatkan beberapa responden untuk melakukan pengujian terhadap sistem yang dibuat.

5) Analisis Hasil Pengujian

Melakukan pengamatan evaluasi dari hasil simulasi dan pengujian yang sudah dilakukan.

6) Penarikan Kesimpulan

Penarikan kesimpulan ini bertujuan untuk menjelaskan kesesuain hasil rancangan untuk diterapkan pada aplikasi yang dibuat, jalan atau tidaknya aplikasi beserta pemenuhan terhadap aspek yang sesuai dengan tujuan.

7) Dokumentasi, Pelaporan dan Publikasi

Tahapan ini bertujuan mendokumentasikan semua hasil dari penelitian dan melaporkan kepada pihakpihak terkait serta mempublikasikan dalam bentuk jurnal atau prosiding.

\subsection{Analisis Kebutuhan Sistem}

\section{A. Analisis Kebutuhan Fungsional}

Sistem yang dikembangkan harus mempunyai kebutuhan fungsional untuk dua pengguna yaitu Admin dan Pengguna Layanan.

\section{Sistem kebutuhan fungsional untuk admin:}

1) Sistem harus dapat login

2) Sistem harus dapat menampilkan menu Home

3) Sistem harus dapat mengelola pengguna

4) Sistem harus dapat mengelola data provinsi

5) Sistem harus dapat mengelola data kabupaten/kota

6) Sistem harus dapat mengelola data produsen mobil, data nama bengkel mobil dan data lokasi bengkel mobil. 
Sistem Kebutuhan untuk Pengguna :

1) Sistem harus dapat memberikan informasi kepada pengguna dalam bentuk teks dan suara ketika perangkat GPS smartphone Android atau koneksi internet pengguna bermasalah.

2) Sistem harus dapat memudahkan pengguna dalam mencari lokasi bengkel mobil resmi, baik dari segi user interface maupun kemudahan dalam menggunakan aplikasi.

3) Sistem harus dapat merespon masukan yang pengguna input dalam mencari lokasi bengkel mobil.

4) Sistem harus dapat memberikan informasi kepada pengguna dalam bentuk teks dan suara ketika pencarian lokasi bengkel mobil resmi tidak ditemukan.

5) Sistem harus dapat menginformasikan kepada pengguna tentang prediksi jarak dan waktu tempuh untuk sampai ke lokasi bengkel mobil resmi dalam bentuk teks dan suara ketika lokasi bengkel mobil resmi ditemukan.

\section{B. Analisis Kebutuhan Non Fungsional}

Kebutuhan non fungsional pada sistem ini meliputi :

a) Kebutuhan Hardware

1) Koneksi internet

2) Koneksi GPS (Global Positioning System)

3) Perangkat PC (Personal Computer) lengkap

4) Smartphone Android

b) Kebutuhan Software

1) Sistem Operasi Windows 8.1.64 bit

2) Sistem Operasi Android (minimal versi Honeycomb/API 11/ Android 3.0)

3) Web Server Apache

4) Database MySQL

5) Framework Code Igniter

6) Eclipse Juno

7) Notepad++

\subsection{Rancangan Use Case Diagram}

Sebelum pengguna menggunakan aplikasi untuk melakukan pencarian lokasi bengkel mobil, admin sistem melakukan pengisian data terkait yang terdiri dari data pengguna/admin, data provinsi, data kabupaten/kota, data produsen dan data bengkel. Data-data tersebut diisi oleh admin sistem menggunakan interface web. Selanjutnya, pengguna dapat melakukan pencarian lokasi bengkel mobil resmi menggunakan interface Android. Pengguna cukup memasukkan nama bengkel, kemudian aplikasi mengolah masukan data dari pengguna untuk ditampilkan dalam bentuk visualisasi peta dengan Google Maps seperti yang diilustrasikan pada Gambar 3.

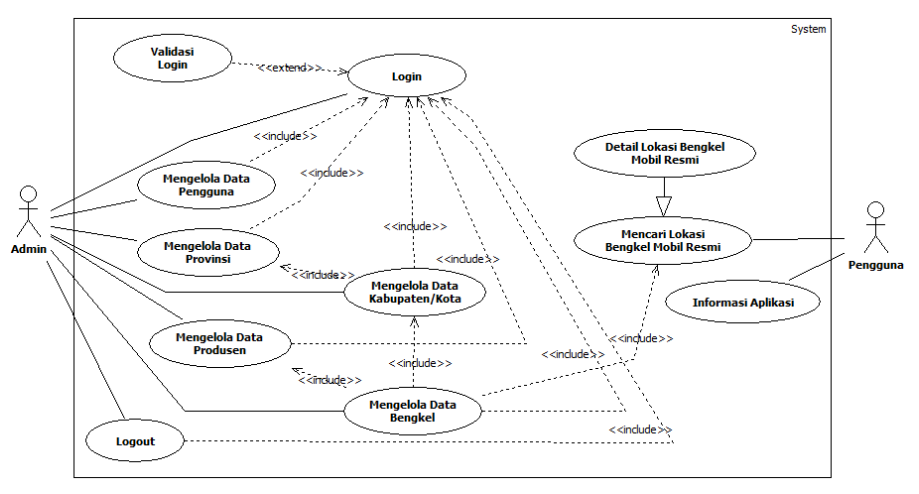

Gambar 3. Rancangan Use Case Diagram

\subsection{User Interface}

\section{A. Form Tampilan Pencarian Lokasi Bengkel}

Form ini adalah form yang tampil pada saat aplikasi android dijalankan pertama kali. Berikut ini tampilan form Pencarian Lokasi Bengkel pada Gambar 4.

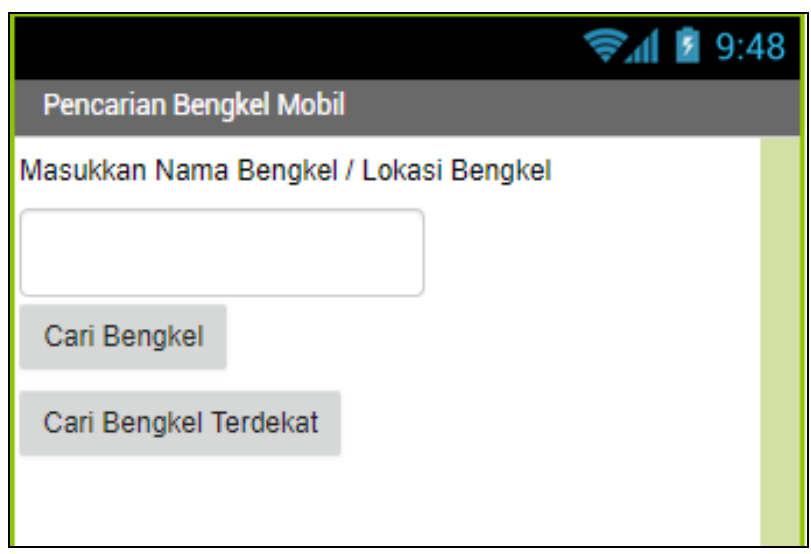

Gambar 4. Tampilan Form Pencarian Lokasi Bengkel

\section{B. Form Tampilan Peta}

Form ini adalah tampilan peta lokasi bengkel yang sudah diinputkan di wilayah Bandar Lampung. Tampilan peta dapat dilihat pada Gambar 5.

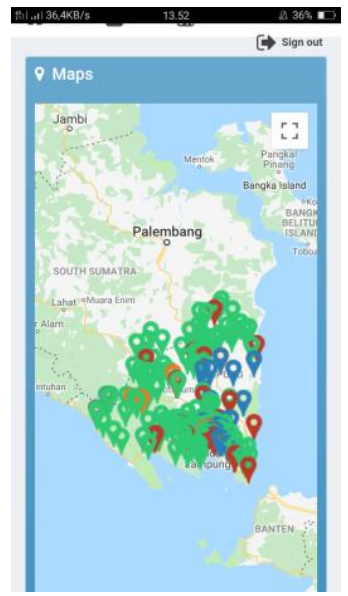

Gambar 5. Tampilan Peta 


\subsection{Hasil Pengujian}

\section{A. Pengujian Black Box}

Pengujian ini digunakan untuk mengukur fungsionalitas dari program dengan memastikan bahwa setiap form dan fungsi dapat berjalan dengan baik (Pressman, 2015). Hasil pengujian black box dapat dilihat pada Tabel 1.

Tabel 1. Hasil Pengujian Black Box

\begin{tabular}{|c|c|c|c|}
\hline No & Unit Testing & Proses Pengujian & $\begin{array}{c}\text { Hasil } \\
\text { Pengujian }\end{array}$ \\
\hline 1 & Form Login & $\begin{array}{l}\text { Memasukkan user } \\
\text { dan password, jika } \\
\text { benar maka akan } \\
\text { masuk ke menu } \\
\text { utama (home), jika } \\
\text { salah maka muncul } \\
\text { peringatan bahwa } \\
\text { user atau password } \\
\text { salah }\end{array}$ & Berhasil \\
\hline 2 & $\begin{array}{l}\text { Form } \\
\text { Pengguna }\end{array}$ & $\begin{array}{l}\text { Mengelola data } \\
\text { pengguna (Simpan, } \\
\text { Ubah dan Hapus) }\end{array}$ & Berhasil \\
\hline 3 & Form Provinsi & $\begin{array}{l}\text { Mengelola data } \\
\text { Provinsi (Simpan, } \\
\text { Ubah dan Hapus) }\end{array}$ & Berhasil \\
\hline 4 & $\begin{array}{l}\text { Form } \\
\text { Kabupaten/ } \\
\text { Kota }\end{array}$ & $\begin{array}{l}\text { Mengelola data } \\
\text { Kabupaten/Kota } \\
\text { (Simpan, Ubah dan } \\
\text { Hapus) }\end{array}$ & Berhasil \\
\hline 5 & $\begin{array}{l}\text { Form } \\
\text { Produsen }\end{array}$ & $\begin{array}{l}\text { Mengelola data } \\
\text { Produsen (Simpan, } \\
\text { Ubah dan Hapus) }\end{array}$ & Berhasil \\
\hline 6 & Form Bengkel & $\begin{array}{lr}\text { Mengelola data } \\
\text { Bengkel (Simpan, } \\
\text { Ubah dan Hapus) }\end{array}$ & Berhasil \\
\hline 7 & $\begin{array}{l}\text { Form Input } \\
\text { Pencarian } \\
\text { Lokasi } \\
\text { Bengkel }\end{array}$ & $\begin{array}{l}\text { Memasukkan lokasi } \\
\text { bengkel mobil yang } \\
\text { dicari }\end{array}$ & Berhasil \\
\hline 8 & Tampilan Peta & $\begin{array}{lr}\text { Menampilkan peta } \\
\text { sesuai dengan } \\
\text { bengkel yang dicari }\end{array}$ & Berhasil \\
\hline
\end{tabular}

Proses pengujian black box testing dilakukan dengan cara melibatkan 10 responden yang meliputi 4 responden yaitu pemilik bengkel mobil, 4 responden pengguna jasa layanan bengkel mobil dan 2 responden yaitu akademisi. Dari 10 responden yang melakukan pengujian black box menyebutkan bahwa semua fungsi program dapat berjalan dengan baik dan sesuai dengan rancangan.

\section{B. Pengujian User Acceptance Testing}

Pengujian ini dilakukan dengan melibatkan 20 responden untuk menilai 4 aspek sesuai dengan standar ISO 9126 (Narimawati, 2008) yang terdiri dari aspek Functionaliti (Fungsionalitas), Reliabiliti (Kehandalan), Usabiliti (Kebergunaan) dan Effciency(Efisiensi). Hasil pengujian dapat dilhat pada Tabel 2.

Tabel 2. Hasil Pengujian User Acceptance Testing

\begin{tabular}{|l|l|l|l|l|}
\hline Aspek & $\begin{array}{l}\text { Skor } \\
\text { Aktual }\end{array}$ & $\begin{array}{l}\text { Skor } \\
\text { Ideal }\end{array}$ & $\begin{array}{l}\text { \% Skor } \\
\text { Aktual }\end{array}$ & Kriteria \\
\hline Functionality & 812 & 900 & $90,22 \%$ & $\begin{array}{l}\text { Sangat } \\
\text { Baik }\end{array}$ \\
\hline Reliability & 416 & 500 & $83,2 \%$ & Baik \\
\hline Usability & 735 & 800 & $91,87 \%$ & $\begin{array}{l}\text { Sangat } \\
\text { Baik }\end{array}$ \\
\hline Efficiency & 238 & 300 & $79,33 \%$ & Baik \\
\hline Total & 2201 & 2500 & $88,04 \%$ & $\begin{array}{l}\text { Sangat } \\
\text { Baik }\end{array}$ \\
\hline
\end{tabular}

Skor aktual didapatkan dari hasil perhitungan dari masing-masing aspek yang diuji, sedangkan skor ideal adalah skor maksimum untuk masing-masing aspek sedangkan persentase skor aktual didapatkan dengan menggunakan persamaan (1).

$\%$ Skor Aktual $=\frac{\text { Skor Aktual }}{\text { Skor Ideal }} \times 100 \%$

Untuk menilai kriteria berdasarkan persentase skor aktual dengan menggunakan acuan pada Tabel 3 .

Tabel 3. Kriteria Penilaian

\begin{tabular}{|l|l|}
\hline \multicolumn{1}{|c|}{ \% Jumlah Skor } & \multicolumn{1}{c|}{ Kriteria } \\
\hline $20,00 \%-36,00 \%$ & Tidak Baik \\
\hline $36,01 \%-52,00 \%$ & Kurang Baik \\
\hline $52,01 \%-68,00 \%$ & Cukup \\
\hline $68,01 \%-84,00 \%$ & Baik \\
\hline $84,01 \%-100 \%$ & Sangat Baik \\
\hline
\end{tabular}

Hasil pengujian user acceptance testing dituangkan dalam grafik pada Gambar 6.

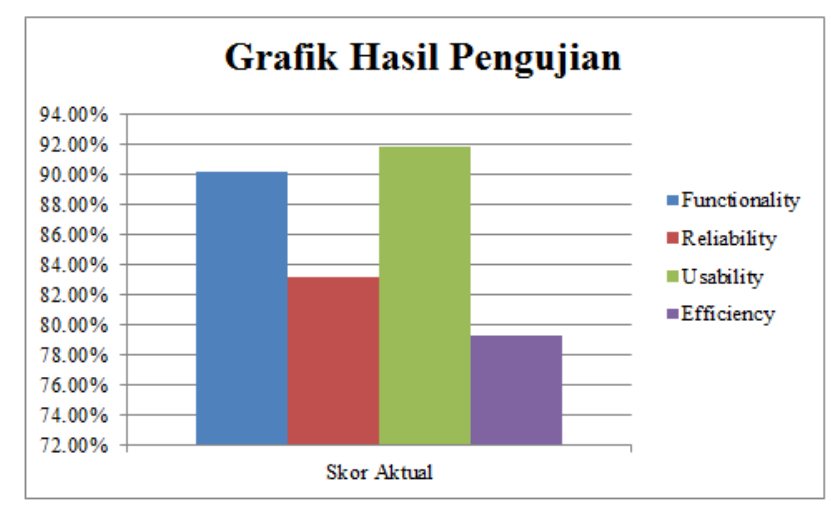

Gambar 6. Grafik Hasil Pengujian User acceptance Testing 
Berdasarkan hasil yang ditunjukkan pada Tabel 2 dan Gambar 11, dapat disimpulkan bahwa tingkat kualitas perangkat lunak sistem informasi geografis pencarian lokasi bengkel mobil di wilayah kota Bandar Lampung secara keseluruhan dalam kriteria Sangat Baik, dengan persentase $88,04 \%$. Aspek kualitas tertinggi adalah berdasarkan aspek Usability dengan persentase sebesar 91,87\%, selajutnya aspek Functionality dengan 90,22\%. Aspek Reliability dengan persentase sebesar 83,2\%, sedangkan aspek kualitas terendah adalah dari aspek Efficiency dengan persentase sebesar 79,33\%.

\section{Kesimpulan}

Aplikasi Sistem Informasi Geografis untuk Pencarian Bengkel Mobil Terdekat di Wilayah Bandar Lampung dapat mempermudah pengguna jasa layanan bengkel dalam mencari lokasi bengkel sesuai keinginan ataupun mencari bengkel terdekat dari titik lokasi pengguna. Aplikasi dapat diterapkan karena sudah sesuai dengan kebutuhan pengguna, hal ini dibuktikan dari dua proses pengujian yang telah dilakukan, yaitu black box testing dengan kesimpulan hasil bahwa semua fitur program dapat berjalan dengan baik dan pengujian berikutnya adalah berdasarkan pengujian menggunakan metode user acceptance testing mendapatkan hasil 88,04 angka ini menunjukkan kriteria sangat baik.

Aplikasi ini juga dapat dikembangkan tidak hanya pada wilayah Bandar Lampung saja, tetapi dapat digunakan pada wilayah lain juga karena sudah disiapkan fitur database untuk menyimpan lokasi bengkel mobil di kabupaten/kota maupun provinsi lainnya sesuai dengan kebutuhan pengguna.

\section{Daftar Pustaka}

BPS., Kota Bandar Lampung, 2019 https://bandarlampungkota.bps.go.id/, diakses pada tanggal 02 Mei 2019.

WIBOWO, K., MUKTI., Sistem Informasi Geografis (SIG) Menentukan Lokasi Pertambangan Batu Bara Di Provinsi Bengkulu Berbasis Website., 2015. Jurnal Media Infotama Vol. 11, No. 1.

MINARNI, Sistem Informasi Geografis Pariwisata Kota Padang Menggunakan Application Programming Interface (API) Google Maps Berbasis Web, 2013. Institut Teknologi Padang, TEKNOIF, Vol. 3 No 1. Hal. 31-37.

DARWIS, D., Aplikasi Kelayakan Lahan Tanam Singkong Berdasarkan Hasil Panen Berbasis Mobile, 2016. Jurnal TEKNOINFO, Vol. 10, No.1, Hal 1-5.

INDRAKARNA, P.A., YUDISUDA., Rancang Bangun Sistem Informasi Pelacakan Dan Pemantauan Paket Kiriman Berbasis Web dengan Bantuan Mobile Android, 2012., Sekolah Tinggi Manajemen Informatika \& Teknik Komputer Surabaya, JSIKA, Vol.1 No.2.
ESKA, J., Geographic Information System Pemetaan Bengkel Sepeda Motor Di Kota Kisaran Berbasis Web. 2018. Vol 1 No 2. Hal 97-102.

SANJAYA, A., Sistem Informasi Geografis Letak Kolam Renang Umum Di Kota Medan Berbasis Android. 2014. Seminar Nasional Informatika. Hal 8-11.

R. KUMALAWATI, R., PRASAJA, A.S., RIJANTA, S.S., RIJAL, J., SARTOHADI, R. PRADIPTYO. Aplikasi Sistem Informasi Geografi dan Penginderaan Jarak Jauh untuk Estimasi Kerusakan Pemukiman Akibat Banjir Lahar di Kecamatan Ngluwar Magelang, 2013 Seminar Nasional Aplikasi Teknologi Informasi. Hal 24-27.

IRWANSYAH, E., ADHINUGRAHA, S., WIJAYA, T.D., Pengembangan Sistem Informasi Geografis (SIG) pada Platform Google untuk Penanggulangan Kebakaran di Jakarta Selatan. 2011 Seminar Nasional Aplikasi Teknologi Informasi. Hal. 7-11.

PRESSMAN, R.S., Rekayasa Perangkat Lunak: Pendekatan Praktisi Buku I. 2015 Yogtakarta : Andi.

NARIMAWATI. U., Metodologi Penelitian Kualitatif dan Kuantitatif : Teori dan Aplikasi. 2008., Bandung : Agung Media. 